\title{
Assessment of Groundwater Water Quality in M'nasra (Morocco)
}

\author{
Mina Elmarkhi*, Sanae Sadek, Khadija Elkharrim, Fatima Benelharkati, \\ Fatiha El Khayyat, Driss Belghyti
}

Environment and Renewable Energy Laboratory, Faculty of Sciences, Ibn Tofail University, Kenitra, Morocco

Email: *minaelm@hotmail.fr

How to cite this paper: Elmarkhi, M., Sadek, S., Elkharrim, K., Benelharkati, F., El Khayyat, F. and Belghyti, D. (2017) Assessment of Groundwater Water Quality in M'nasra (Morocco). Journal of Water Resource and Protection, 9, 111-120. https://doi.org/10.4236/jwarp.2017.92009

Received: December 5, 2016

Accepted: February 1, 2017

Published: February 4, 2017

Copyright $\odot 2017$ by authors and Scientific Research Publishing Inc. This work is licensed under the Creative Commons Attribution International License (CC BY 4.0).

http://creativecommons.org/licenses/by/4.0/

\begin{abstract}
The consumption of non-potable water is the main cause of mortality and morbidity in the world [1]. $88 \%$ of diarrhea cases worldwide are attributed to unsafe drinking water; inadequate sanitation or inadequate is responsible for 1.5 million of deaths every year, mostly in children [1] [2]. Household waste. Leachate can be considered among the potential sectors that can contribute to the degradation of water quality and soil. To this end, we selected physicochemical inorganic elements like indicator of pollution in the neighboring groundwater discharge of the water table in the region of Ouled Berjal to assess the quality of the region's water wells in M'nasra. The wells in full discharge have a very high pollution levels and water collected from wells located right near the discharge of Ouled Berjal shows lower levels of contamination. So the well water away from the landfill is quite low compared to the other groups.
\end{abstract}

\section{Keywords}

Pollution, Physico-Chimique, La Décharge D’Ouled Berjal, Kenitra, Maroc

\section{Introduction}

This product of the dissolution of organic matter and trace elements (heavy metals, organic pollutants and chemicals, radionuclides...) is a source of pollution of soil and water, including groundwater. Among the inorganic compounds found in raw leachate are the heavy metals that attract attention because of their potential toxicity. Although these substances are generally present at low concentrations in the leachate (with the exception of iron and manganese), some can be dangerous if they infiltrate at a source of drinking water. The microbiological contamination, parasitological, biological and physicochemical water from groundwater poses real public health problem [3] [4] [5]. 


\section{Milieu Materials and Methods Study}

\subsection{Study Milieu}

The samples were taken 23 wells, three wells (P21, P22, P23) are located inside the discharge, three other are adjacent to the discharge (P15, P16 and P17) and the remainder wells (P1, P2, .., P20) distributed in the study area of M'nasra region. These samples are filled into plastic bottles and then sent to the laboratory ORMVAG, Kenitra. To better exploit the data collected, we have divided them into three groups according wells the distance that separates them from the source:

- Group 1 where the wells are within the discharge is composed of the wells 21; 22 and 23.

- Group 2 consists of moderately distant from the discharge shaft (15; 16 et 17).

- Group 3 includes the remaining wells often further.

\subsection{Materials and Methods Study}

\begin{tabular}{ccc}
\hline Parameters & Unit & Equipment used \\
\hline Turbidity & NTU & Turbidity \\
Potential hydrogen & - & PH-meter model HANNA instruments. \\
Electrical conductivity & us/cm & Multi-parameter analyzer CONSORT-C535 \\
Salinity & $\mathrm{mg} / 1$ & Multi-parameter analyzer CONSORT-C535 \\
$\begin{array}{c}\text { Calcium, magnesium, } \\
\text { chlorine, bicarbonate } \\
\text { Nitrate, ammonium }\end{array}$ & $\mathrm{mg} / \mathrm{l}$ & Titration solution \\
Potassium and Sodium & $\mathrm{mg} / 1$ & Distillation apparatus (BUSHI) \\
\hline
\end{tabular}

\section{Results and Discussion}

\subsection{Potential Hydrogen}

The distribution of the potentials of hydrogen according to the distances which separates the relief wells also shows a highly significant difference (Fisher $=7.41$; $p<0.001)$. The mean of the classification by the Tukey test, these three groups shows that the wells in the discharge have a slightly basic $\mathrm{pH}(\mathrm{pH}=7.83)$, followed by the other wells which are either at an average distance or far from the source with a $\mathrm{pH}$ of 7.43 and 7 respectively, 39. In addition, the three groups were very uniform in having a very low coefficient of variation ranging from $0.33 \%$ to $0.74 \%$ (Figure 1 ).

For the irrigation water, usually the recommended $\mathrm{pH}$ is between 6.5 and 8.5 [6] because a low $\mathrm{pH}$ promotes the growth of filamentous fungi and other responsible bodies floating sludge [7]. The measured $\mathrm{pH}$ values are acceptable according to Moroccan standards of the quality of groundwater and which are generally between 5.5 and 8.5 (Ministry of Environment, 2002). 


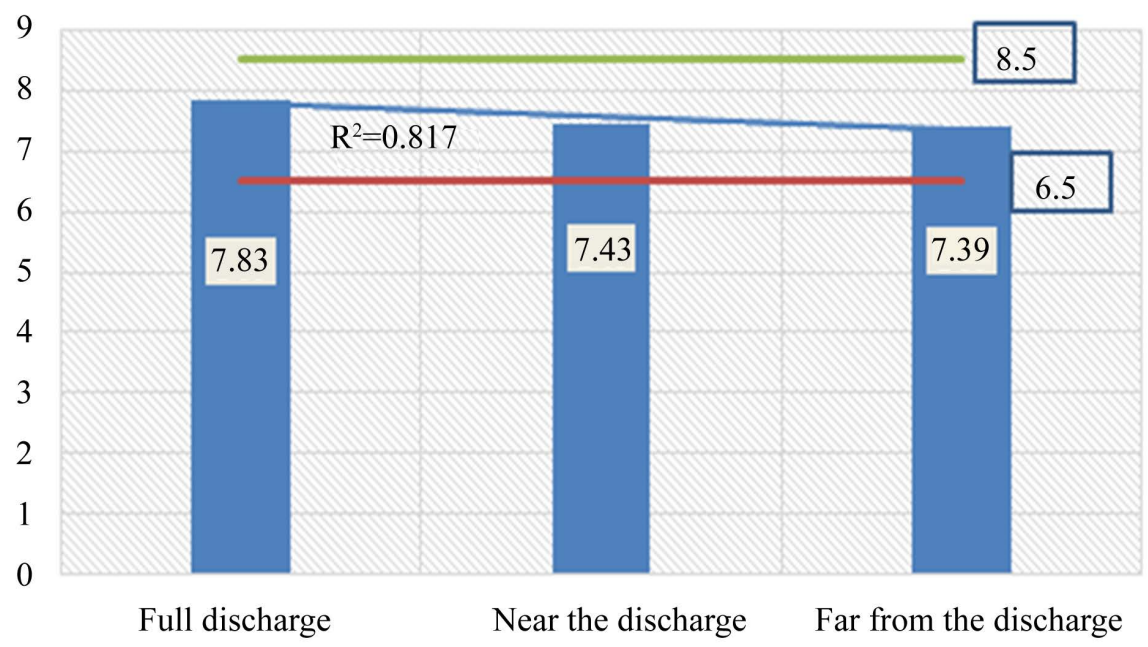

Figure 1. Evolution of hydrogen water potential wells as a function of distance.

\subsection{Electrical Conductivity (EC)}

To locate the status of wells in the three groups, we proposed to establish a variance analysis to a single dimension effect "distance". The results of this analysis show a highly significant difference $(p<0.000)$ between the mean of the conductivity of the groups studied. The comparison of averages Tukey identified three non-overlapping groups. Group 1 comprise the wells in full discharge with a conductivity of up to $3.34 \mathrm{~ms} / \mathrm{cm}$, group 2 close to the landfill with an average conductivity of $1.42 \pm 0.073$ and end wells located at a significant distance from the source and which are characterized by low conductivity values $(0.68 \pm$ 0.021). The evolution of the average conductivity in wells of group 1 were very homogeneous ( $\mathrm{CV}=0.00 \%)$ opposite wells of the groups 2 and 3 show, respectively, significant variation coefficient of $35 \%$ and $43 \%$ (Figure 2).

However, groundwater discharge show high mineralization of about 3.33 $\mathrm{ms} / \mathrm{cm}$. This pollution occurs through two mechanisms: direct contamination which occurs at the discharge career and due by Contact leachate with the tablecloth that goes back to the bottom of quarries; indirect contamination due to infiltration and percolation of leachate through the soil and the unsaturated in general permeable area. It is favored by the shallow depth of the water table (4 $\mathrm{m})$. This pollution is then spread in the same direction as that of the flow of the web to achieve the wells located in the vicinity of the landfill site. This explains the high conductivity values stored at the nearest well. These results agree with those obtained by El-Kharmouz [8] and greater than those found by [9]. Many factors could influence the local conductivity of water such as the amount of mineral or organic matter in suspension, the physicochemical quality of urban, agricultural or industrial discharges and evaporation phenomen. The determined average value is greater than $2.7 \mathrm{~ms} / \mathrm{cm}$, considered direct discharge limit value. Therefore, water well in the group 1 are unfit for irrigation and those of groups 2 and 3 correspond somehow to national standards. So we can classify these waters in the grid of underground water of very poor quality $>3000 \mathrm{~ms} / \mathrm{cm}$ to $25^{\circ} \mathrm{C}$. 


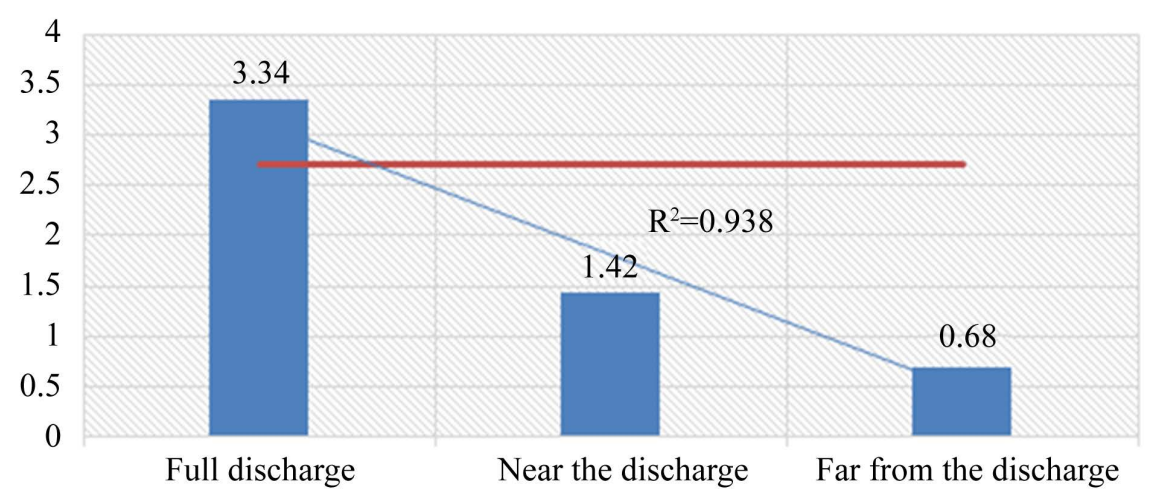

Figure 2. Evolution of the electrical conductivity of the water of wells as a function of distance.

\subsection{Salinity}

The results in showed that the distance between the wells in the discharge is a classification criterion, the difference is therefore very highly significant (Fisher $=781.52, p<0.000)$. Three categories were deduced by the Tukey test. Indeed, a first category represented by the distant wells of the discharge (mean $=0.436$ $\mathrm{g} / \mathrm{l})$, followed by Group 2 (mean $=0.907 \mathrm{~g} / \mathrm{l})$ and finally the category of wells in the landfill (wells 21, 22 and 23) with a concentration of $2.13 \mathrm{~g} / 1$. high dispersion was pronounced in groups 2 and 3 respectively, with coefficients of variation of $39.12 \%$ and $51.57 \%$ (Figure 3 ).

\subsection{Hardness: Calcium $\left(\mathrm{Ca}^{2+}\right)+\left(\mathrm{Mg}^{2+}\right)$ (Mineral Matter)}

The results of the analysis of variance shows that the factor "distance" in a very highly significant (Fisher $=247.720 ; p<0.000$ ). Therefore, the comparison of average class sinks into three distinct categories. The first category consists of the further well (group 3) and having registered moderately lower concentrations. The second category includes the well in the group 2 (sufficient distance greater than that of group 1) with an average of $183.04 \pm 8.92 \mathrm{mg} / \mathrm{l}$ and a group variation of $33.75 \%$. However, the group of wells located in the heart of the landfill is isolated from the other groups, while mean values with significant $\mathrm{Ca}^{2+}+$ $\mathrm{Mg}^{2+}($ mean $=249.12 \pm 8.2 \mathrm{mg} / \mathrm{ml})$.

Furthermore, the recorded concentrations well above those set as appropriate limits, by the Moroccan authorities. These values indicate that the waters especially the first two groups are assumed to be very hard (Figure 4). The total hardness of water is produced by calcium and magnesium salts contained therein. This parameter has a large variation which is linked to the lithology of the aquifer and in particular to the composition of magnesium and calcium. Rock formations containing divalent metals $\left(\mathrm{Mg}^{2+}, \mathrm{Ca}^{2+}, \ldots\right)$ are responsible for the hardness.

\subsection{Calcium $\left(\mathrm{Ca}^{2+}\right)$ (Mineral Matter)}

The graphical representation of the $\mathrm{Ca}^{2+}$ content per well revealed a large dispersion among them. This variation is of the order of $43.9 \%$ is approved by an 


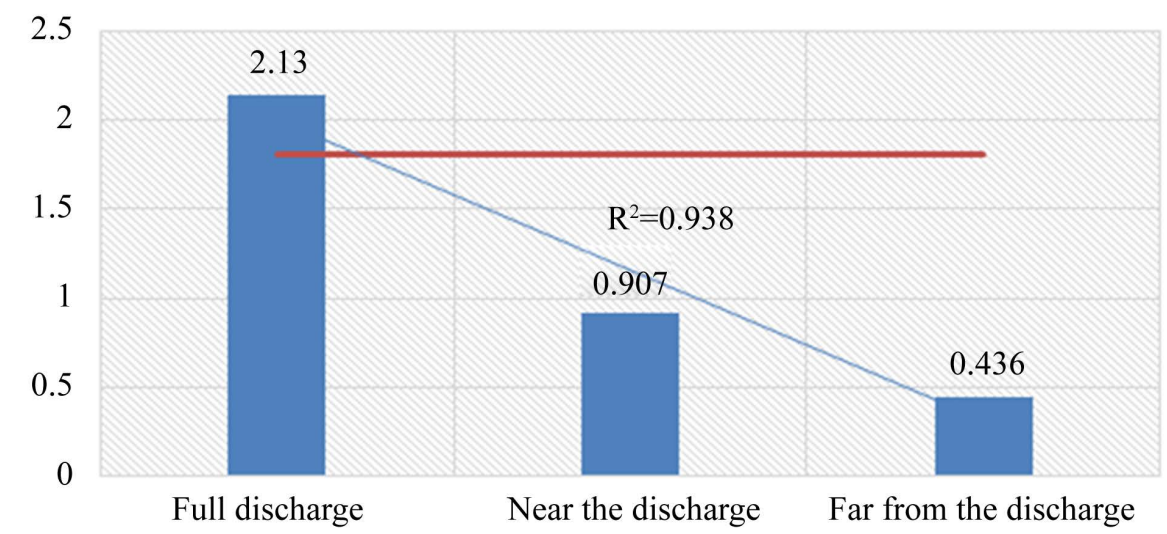

Figure 3. Evolution of the salinity of wells as a function of distance.

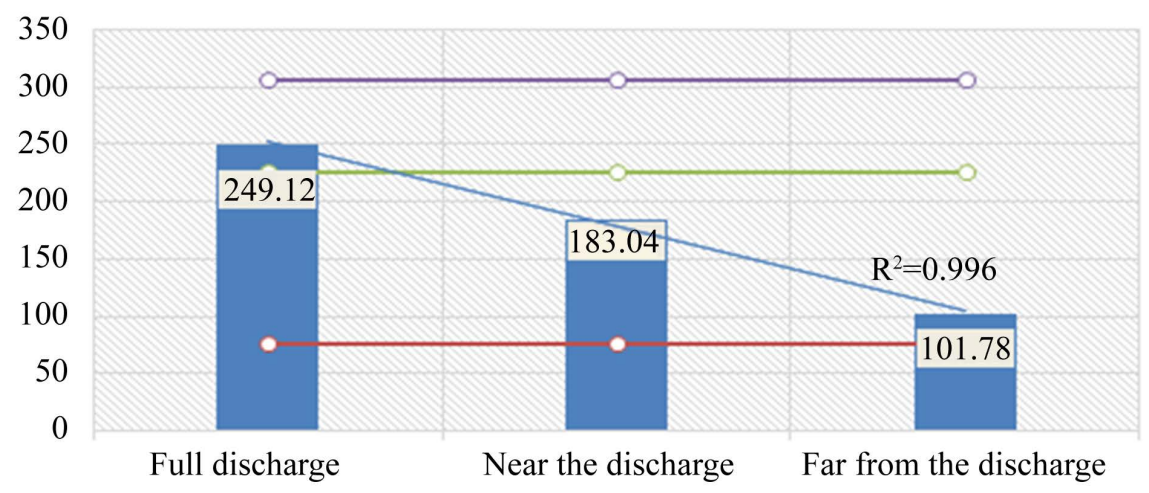

Figure 4. Evolution of the hardness of the water wells depending on the distance.

analysis of variance one-dimensional "effect well" who was very highly significant (Fisher $=71.53 ; p<0.000)$. The lowest content $(38.40 \mathrm{mg} / \mathrm{l})$ is recorded in the well 19 and a maximum concentration of $237.60 \mathrm{mg} / \mathrm{l}$ is displayed in the 15 wells.

A highly significant difference was marked between the averages of the three groups, and their classification did retain two non-overlapping categories. The first category consists only of group 3 whose average grade is low (Mean $=92.62$ $\mathrm{mg} / \mathrm{l})$, the second category includes the Group 1 and 2 which display relatively high concentrations (168.48 and 163.30). The group variation exceeds $28 \%$, this explains many nonseasonal stability $\mathrm{Ca}^{2+}$.

Possible negative correlation was marked between the distance between the well source and also of the $\mathrm{Ca}^{2+}$ content. From Figure 5, these values often exceed accepted standards for water consumption for group 1 and group 2. This shows a pollution of groundwater by calcium probably from the discharge through the leachate.

\subsection{Magnesium ( $\left.\mathrm{Mg}^{2+}\right)$ (Mineral)}

This variation is much more visible, while collecting this to the distance between the wells in the discharge Ouled Berjal. Nevertheless, analysis of variance, followed by the test shows Tukey plain good discrimination intra and inter group. Three categories (Fisher $=17446.02 ; p<0.000$ ), therefore, have been described. 


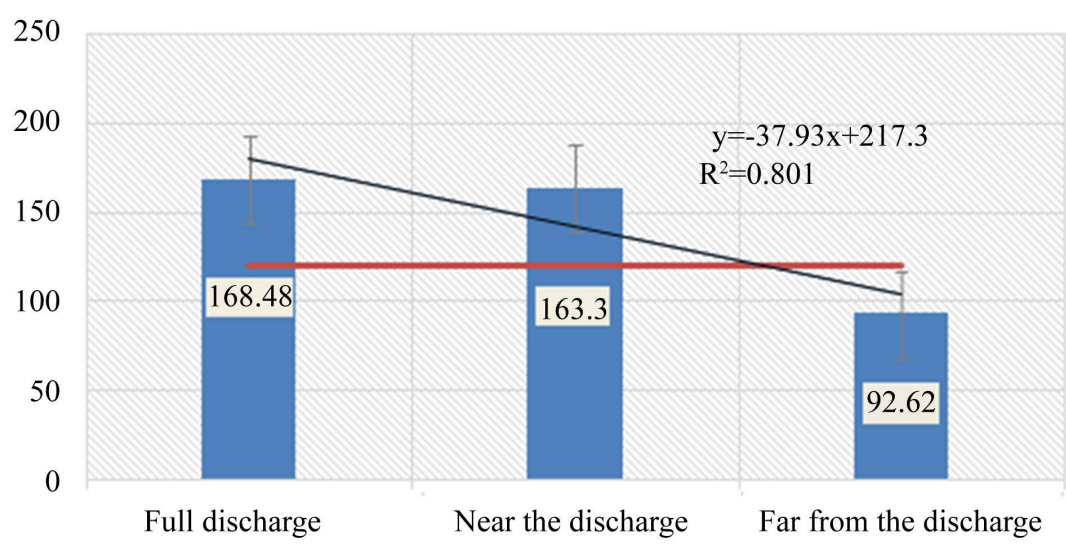

Figure 5. Evolution of the calcium water wells depending on the distance.

The first category is composed of the said further shaft and which are characterized by a concentration of $9.14 \pm 4.79$. The second category includes the well in the group 2 and which are characterized by an average concentration of 19.74 $\mathrm{mg} / \mathrm{l}$. The last category includes the well having a relatively high average $80.4 \pm$ $4.22 \mathrm{mg} / \mathrm{l}, 95 \%$ of the observations are grouped around this average value $(\mathrm{CV}=$ $5.23 \%$ ) (Figure 6).

Figure 6 the higher magnesium concentration is observed in the discharge with an average of $80.64 \mathrm{mg} / \mathrm{L}$ which exceeds the standard Moroccan what set at $50 \mathrm{mg} / \mathrm{l}$ (Ministry of Environment, 2002), this implies a change in the mineralization of the waste. The analysis showed an average concentration of well water is of the order of $11.26 \mathrm{mg} / \mathrm{l}$ with a minimum of $1.91 \mathrm{mg} / \mathrm{l}$ and a maximum of $26.4 \mathrm{mg} / \mathrm{l}$.

\subsection{Sodium ( $\mathrm{Na}^{+}$) (Mineral Matter)}

Analysis of variance single factor "distance effect" gives a fairly high value of Fisher $(\mathrm{F}=3215.85)$. The effect therefore of the distance between the borings is very highly significant $(p<0.000)$. The comparison of averages has classified these groups into three distinct categories. The first category is characterized by very low average concentrations $(=58.83 \pm 2.49 \mathrm{mg} / \mathrm{l})$ and the third category for the further shaft is marked this time by very high levels $(=949.67 \pm 19.72 \mathrm{mg} / \mathrm{l})$. Wells groups 2 and 3 have identified a wide variation intra category respectively resulted in coefficients of variation of $74.52 \%$ and $60.85 \%$ (Figure 7 ).

\subsection{Potassium $\left(\mathrm{K}^{+}\right)$(Mineral Matter)}

Analysis of variance shows that the distance between them to have a major effect on the potassium content. The comparison of means by the Tukey resortir test has three non-overlapping categories. The first category includes wells that are far from the discharge (mean $=5.23 \mathrm{mg} / \mathrm{l}$ ) and the third category contains wells that displayed contents $\mathrm{K}^{+}$very high $($mean $=33.30)$ (Figure 8).

\subsection{Ammonium $\left(\mathrm{NH}_{4}^{+}\right)$}

Analysis of variance single factor "distance effect" shows that the distribution of 


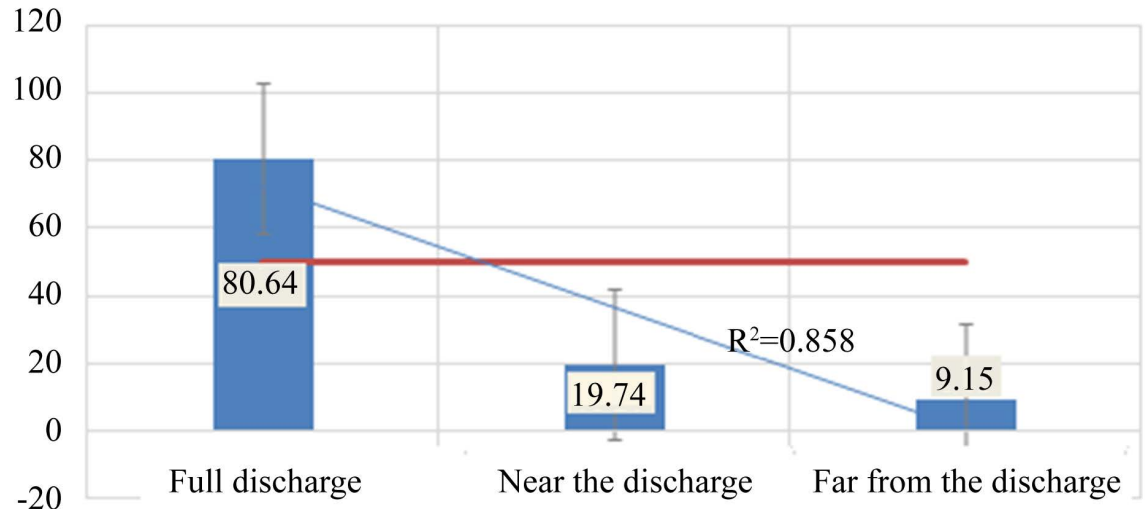

Figure 6. Evolution of Magnesium water wells depending on the distance.

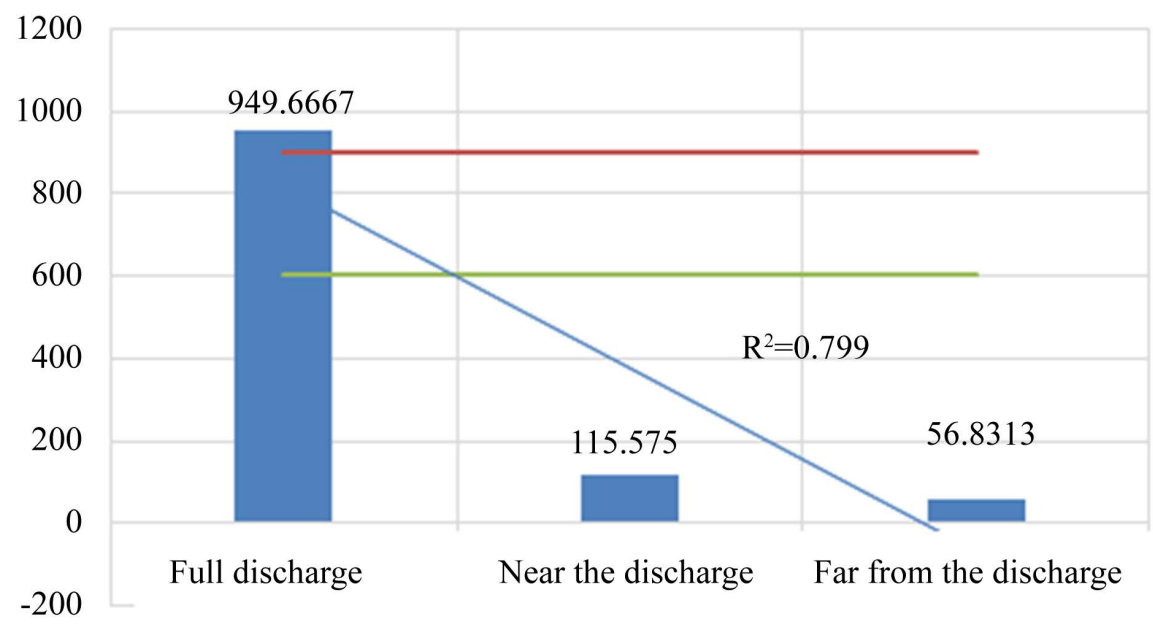

Figure 7. Evolution of Sodium Water wells depending on the distance.

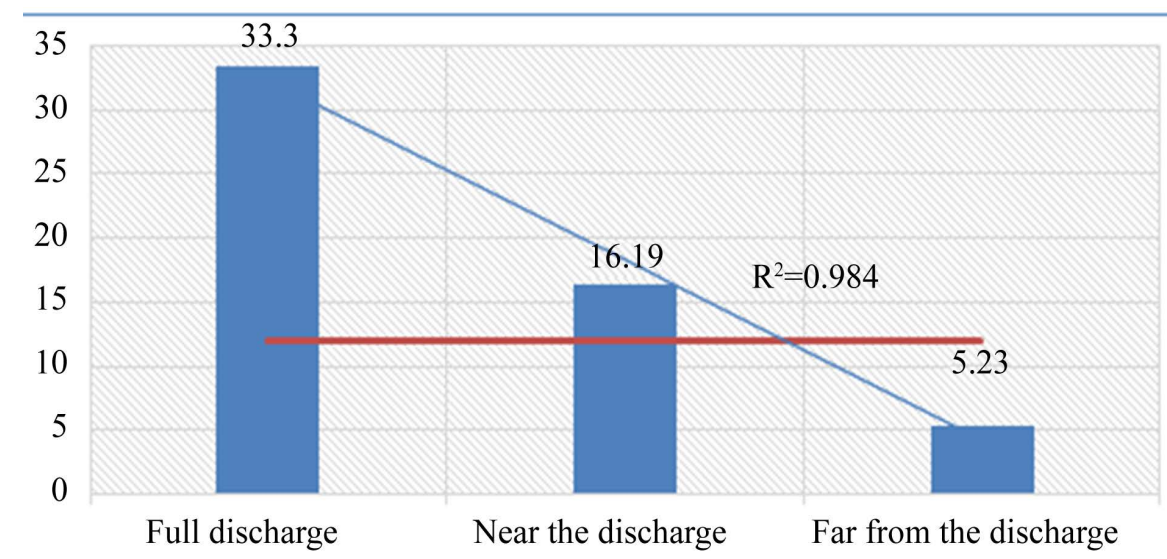

Figure 8. Evolution of Potassium water wells depending on the distance.

the average grade has a highly significant difference (Fisher $=358.31, p<0.000$ ). Furthermore, the average comparison enabled to distinguish two classes, first class is composed of one well in the group that recorded an average of $5.01 \pm$ 0.078 and a second class bringing together well in groups 2 and 3. A high dispersion is marked in the latter two groups $(\mathrm{CV}=28.64 \%, \mathrm{CV}=32.14)$ (Figure 9). 


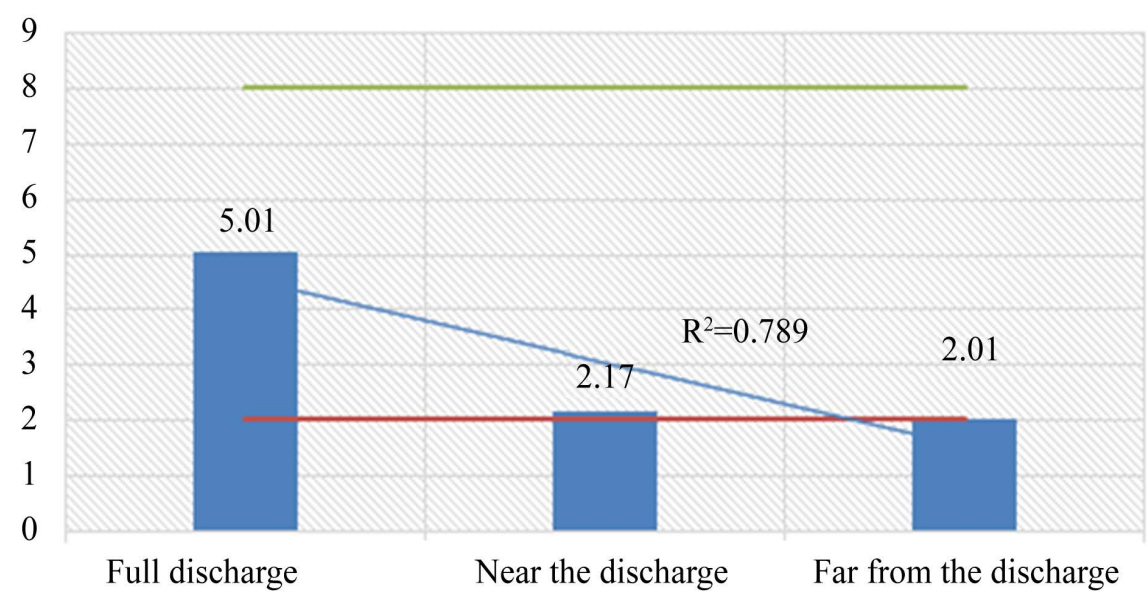

Figure 9. Evolution Ammonium water wells depending on the distance.

\subsection{Chloride $\left(\mathrm{Cl}^{-}\right)$}

The results of the analysis of variance show that the distance separating the discharge shaft has a major effect on the distribution of the chlorine content (Fisher $=4321.74 ; \mathrm{p} 0.000)$. This dispersion was possible to classify the wells into three groups. Indeed, the well of the first group showed concentrations ranging 609 $\mathrm{mg} / \mathrm{l}$ and $820 \mathrm{mg} / \mathrm{l}$ and those in the third group; they fluctuate between $35.5 \mathrm{mg} / \mathrm{l}$ and $161.4 \mathrm{mg} / \mathrm{l}$ (Figure 10).

\subsection{Nitrate $\left(\mathrm{NO}_{3}^{-}\right)$}

ANOVA confirmed the highly significant effect of the position of the wells on the distribution of concentrations. The average comparison revealed 14 distinct groups; the latter group is made up of wells that displayed high levels of $\mathrm{NO}_{3}^{-}$ (Figure 11).

Analysis of variance "distance effect" shows a highly significant difference. Perfect discrimination was reported, resulting in three non-overlapping groups, maximum values were recorded in group 1, group 2 and then followed a third group where wells are not too loaded ion $\mathrm{NO}_{3}^{-}$.

\subsection{Bicarbonate $\left(\mathrm{HCO}_{3}^{-}\right)$}

Analysis of variance for a single classification factor shows that the position of the well has a highly significant effect on the distribution of concentrations of bicarbonate (Fisher $=1539.37 ; p<0.000$ ), and the distance between these wells to landfill (Fisher $=394.26 ; p<0.000$ ) (Figure 12). However, the comparison of means was possible to classify the wells in order of increasing bicarbonate concentration, so the closest are most likely to be contaminated with bicarbonates.

\subsection{Sulphate $\left(\mathrm{SO}_{4}^{2-}\right)$}

The ANOVAI shows that the distance to a highly significant effect on the dispersion of the concentrations determined on the relevant wells. Moreover, the 


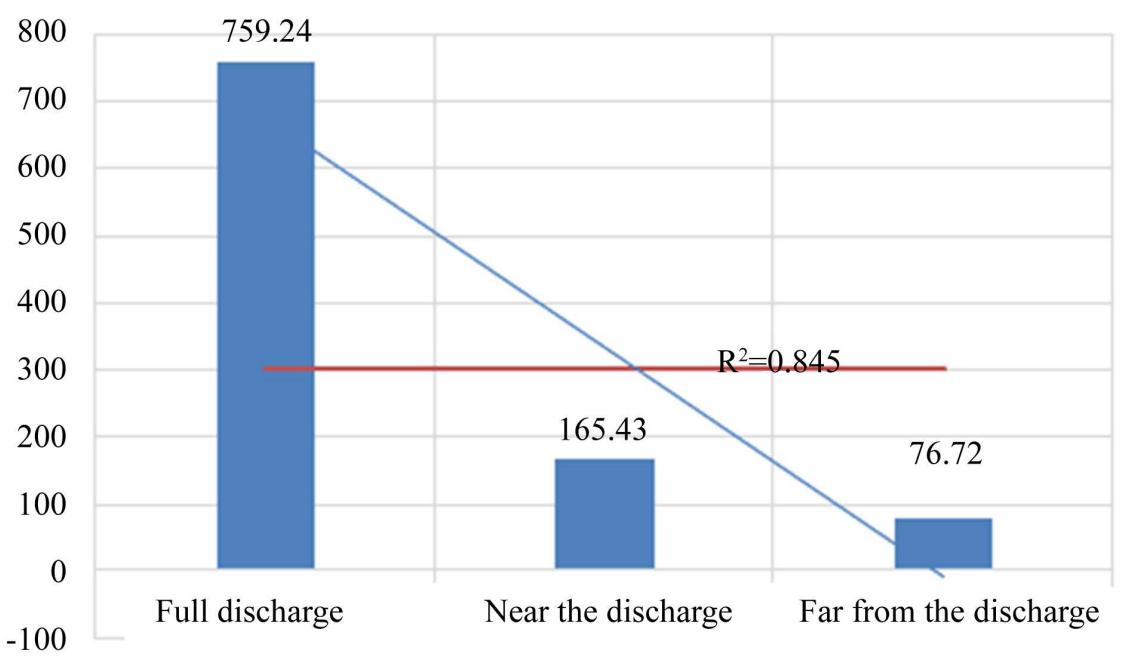

Figure 10. Evolution of chloride water wells depending on the distance.

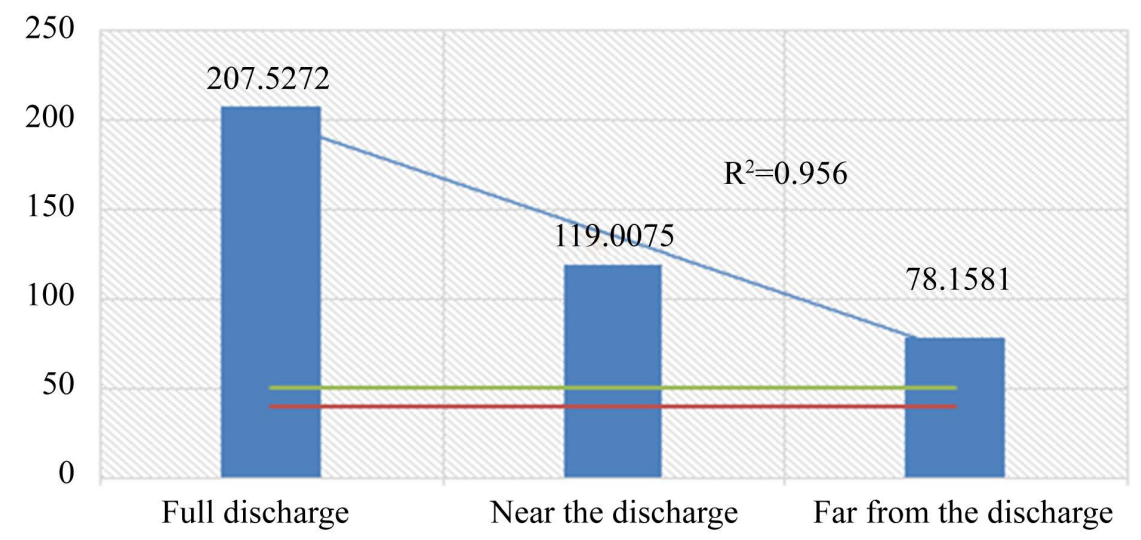

Figure 11. Evolution of nitrate water wells depending on the distance.

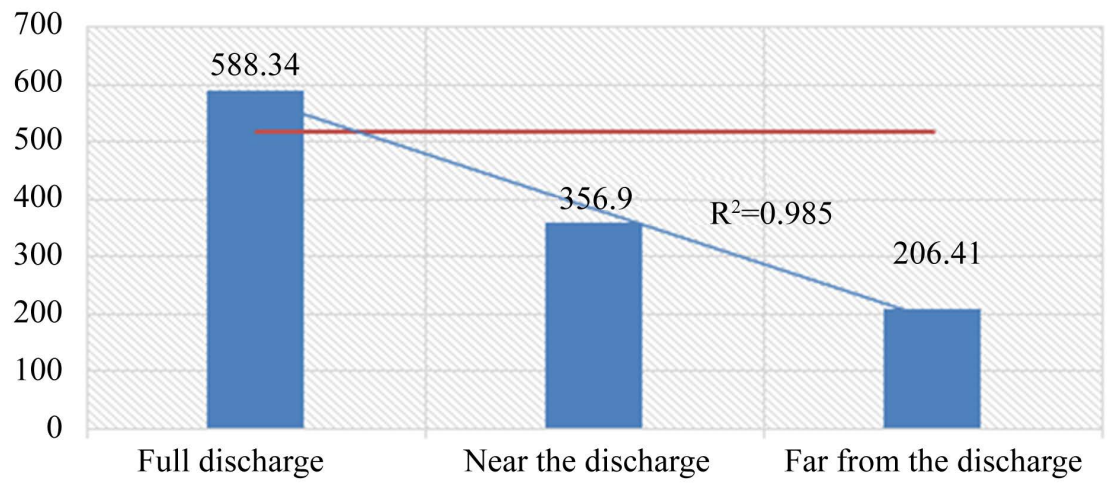

Figure 12. Evolution of the bicarbonate water wells depending on the distance.

comparison of means gave three non-overlapping categories, further were less sensitive to concentrations of $\left(\mathrm{SO}_{4}^{2-}\right)$.

The distribution contents $\left(\mathrm{SO}_{4}^{2-}\right)$ as a function of the monthly variation shows no significant differences $(\mathrm{F}=0.01 ; p=1)$, but the observations have fluctuated between a minimum value of $12.86 \mathrm{mg} / \mathrm{l}$ and a maximum value of $600.38 \mathrm{mg} / \mathrm{l}$ (Figure 13). 


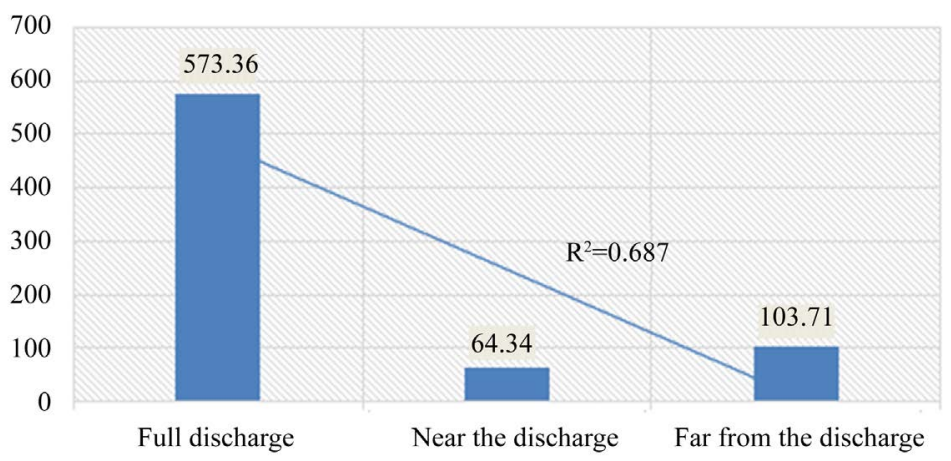

Figure 13. Evolution of Sulfate water wells depending on the distance.

\section{Conclusion}

The study of parameters indicative of contamination from leachate generated by the discharge of Ouled Berjal allowed us to identify a mineral water contamination of the water table. Indeed, it is the water collected from wells 21, 22 and 23, located right in the landfill and in the flow direction of the web which are the most vulnerable to contamination mineral, organic, and inorganic things.

\section{References}

[1] OECD (2003) Biotechnology for Water Use and Conservation. The Mexico '96 Workshop.

[2] Pruss-Üstün, A., Bos, R., Gore, F. and Bartram, J. (2008) Safer Water, Better Health: Costs, Benefits and Sustainability of Interventions to Protect and Promote Health. World Health Organization, Geneva, 60.

[3] Scanlon, B.R., Reedy, R.C., Stonestrom, D., Prudic, D.D.D.E. and Dennehy, K.F. (2005) Impact of Land Use and Land Cover Change on Groundwater Recharge and Quality in the Southwestern US. Global Change Biology, 11, 1577-1593. https://doi.org/10.1111/j.1365-2486.2005.01026.x

[4] El-Naqa, A., Al-Momani, M., Kilani, S. and Hamouri, N. (2007) Groundwater Deterioration of Shallow Groundwater Aquifers Due to Overexploitation in Northeast Jordan. CLEAN-Soil, Air, Water, 35, 156-166.

https://doi.org/10.1002/clen.200700012

[5] Eblin, S.G., Sombo, A.P., Soro, G., Aka, N., Kambiré, O. and Soro, N. (2014) Hydrochemistry of Surface Water in the Region Adiake. Journal of Applied Biosciences, 75, 6259-6271. https://doi.org/10.4314/jab.v75i1.10

[6] Eddy, M. (1991) Wastewater Engineering: Treatment, Disposal, and Reuse. 3rd Edition, McGraw-Hill, New York.

[7] Arcand, Y., Paris, J., Rouleau, D. and Mayer, R. (1989) Effect of Operation Parameters on the Settling of Organic Sludge from a Treatment Unit of Refinery Waste Water. Journal of Water Science, 2, 43-69.

[8] El-Kharmouz (2011) Studying the Impact of Leachate from the Old Landfill of the City of Oujda (Eastern Morocco) on the Physicochemical Quality of Groundwater and Surface Water. Larhyss Journal, No. 16, 105-119.

[9] Khattabi, H. (2002) Study Interests Hydrogeological and Hydro-Biological Parameters for Understanding the Operation of the Leachate Treatment Plant for Household Waste Landfill Etueffont (Belfort, France). PhD Thesis, University of Franche Comte, Universitaire D'Ingénieurs de Lille, France, 171 p. 
Submit or recommend next manuscript to SCIRP and we will provide best service for you:

Accepting pre-submission inquiries through Email, Facebook, LinkedIn, Twitter, etc. A wide selection of journals (inclusive of 9 subjects, more than 200 journals)

Providing 24-hour high-quality service

User-friendly online submission system

Fair and swift peer-review system

Efficient typesetting and proofreading procedure

Display of the result of downloads and visits, as well as the number of cited articles Maximum dissemination of your research work

Submit your manuscript at: http://papersubmission.scirp.org/

Or contact jwarp@scirp.org 